\title{
EGY 21. SZÁZADI TUDÓS A 20. SZÁZADBAN - HANKISS ELEMÉR ÉLETEI
}

\section{A $21^{\text {ST }}$ CENTURY SCIENTIST IN THE $20^{\text {TH }}$ CENTURY - ELEMÉR HANKISS'S LIVES}

\author{
Csepeli György \\ az MTA doktora, szociálpszichológus, a kőszegi Felsőbbfokú Tanulmányok Intézete kutatója \\ gyorgy.csepeli@iask.hu
}

\begin{abstract}
ÖSSZEFOGLALÁS
Írásom témája a Hankiss Elemér tudományos érdeklődésében bekövetkezett "szociológiai fordulat", hiszen a huszadik század hatvanas éveiben még kiváló irodalomkritikusként indult pályáján. A hetvenes években kezdett szociológiával foglalkozni, különösen az értékek kutatása érdekelte, amely páratlan lehetőséget kínált a magyar társadalom megújulási lehetőségeinek feltárására. Ezt követően alkotta szociálpszichológiai diagnózisait, és olyan új fogalmakat, elméleteket „talált ki", amelyeket a magyar és közép-európai társadalmak vizsgálatában máig érvényes elméleti mintáknak tekinthetünk.
\end{abstract}

\section{ABSTRACT}

The paper focuses on the sociological turn in the scholarly interest of Elemér Hankiss who has started his carrier as an eminent literary criticist in the sixties of the twentieth century. In the seventies his interest had turned toward sociology. He had especially been engaged in the research of values that offered a unique opportunity to reveal the reform potential of the Hungarian society. Subsequently he created his social psychological diagnoses, invented new concepts and theories which can be considered as enduring theoretical specimens in the investigations of the Hungarian and Central-European societies.

Kulcsszavak: Hankiss, Kőszeg, irodalmár, szociológia, rendszerváltás

Keywords: Hankiss, Kőszeg, litterateur, sociology, democratic transformation 


\section{A RÖVID ÉVSZÁZAD}

Hankiss Elemér 1928-ban született, s 2015-ben halt meg. Eric Hobsbawm „rövid évszázadként" jellemezte a 20. századot, mely Hobsbawm szerint 1914-ben kezdődött, s 1989-ben ért véget. A század rövid volt, de eseményekben annál gazdagabb. Magyarország különösen nem szenvedett hiányt eseményekben, melyek mikor történtek, testi-lelki kínt és szenvedést hoztak lakosainak. A kínok és szenvedések ráadásul nem múltak el, nyomaik betokozódtak, részeivé válva a később születettek szocializációjának.

Hankiss Elemér szülővárosa, Debrecen, a magyar történelem emblematikus helyszíne. Hankiss apja, Hankiss János az 1912-ben megalapított Magyar Királyi Tudományegyetem professzora, az európai összehasonlító irodalomtudomány kutatója. A két világháború között a debreceni egyetem virágkorát élte, mely elválaszthatatlan Klebelsbeg Kunó 1922 és 1931 között müködött vallás- és közoktatásügyi miniszter müködésétől. Klebelsberg úgy vélte, hogy a trianoni békeszerződés okozta sokkra a magyar társadalom lelki tartalékainak megerősítésével kell reagálni, melyek forrásaként a kultúrát jelölte meg. A debreceni egyetem fejlesztése e kultúrafejlesztő program része volt. Az egyetem a város Nagyerdőnek nevezett ligeti részében nagyszabású, pompás épületet kapott, melyet a professzorok számára épített villák gyürüje vett körül. Hankiss Elemér az egyetem gyönyörü szellemi és fizikai környezetében töltötte gyermekkorát. Apját Kállay Miklós miniszterelnök 1943-ba meghívta kormányába, ahol államtitkárként a közoktatással kapcsolatos ügyek intézése volt a feladata. A megbízatás 1944. március 19-én ért véget, amikor Magyarországot megszállták a német csapatok.

\section{NEMZEDÉKI SORSPÁLYÁK}

A második világháborús események egybeestek Hankiss Elemér életének korai évtizedeivel. Hankiss Elemér nem volt egyedül. A trianoni trauma, a revíziós sikerek okozta eufória, a holokauszt, a második világháború frontjának átvonulása, a demokratikus fordulat, majd az azt követő kommunista terror élményközösséggé forrasztotta az 1920-as években született fiatalokat, létrehozva egy új nemzedéket. Mannheim Károly jogosan mutat rá, hogy a nemzedéki létnek csak egyik feltétele a születés naptári egyidejüsége. Sokkal fontosabb a másik feltétel, a történelmi élmények közös megélése, melynek révén a naptári születés időpontja alapján adott korcsoport tagjai sorsközösségként tekintenek magukra. A sorsközösség azonosságán belül jönnek létre az egymástól elágazó sorspályák.

A jövőbe éppen belépő akadémiai generáció tagjai korántsem egységesen reagáltak a múlt eltünésére. Voltak, akik megérezve a várható megpróbáltatásokat, 
nem vállalták, hogy tanuló- és alkotó éveiket Magyarországon éljék le. Nyugatra mentek, ahol tehetségük, szorgalmuk lehetővé tette a legjobb akadémiai stallumok megszerzését. A sok kínálkozó példa közül megemlíthető Szabó Dénes kriminológus, Lámfalussy Sándor közgazdász. Mindketten megmaradtak magyarnak, de életművük kiszakadt a magyar kultúra kontextusából (Csepeli et al., 2015).

Itthon maradtak, akik a fényes szelek káprázatában a magyar jövő alakítására vágytak. A cselekvés terepét a Kommunista Párt kínálta, mely az összeomlás zűrzavara okozta bizonytalanságból a kollektív boldogság utópiájának bizonyosságát ígérte. Szélsőséges példa Lakatos Imre, aki lelki alkata alapján akár egyike lehetett volna a Dosztojevszkij által „ördögöknek” nevezett terroristáknak. A háború alatt egy titkos kommunista sejt tagjaként rávette egyik csoporttársát, hogy a csoport megmentése érdekében kövessen el öngyilkosságot. A háború után a Kommunista Párt ideológusa, Révai József kíméletlen politikájának engedelmes végrehajtója lett. Részt vett az Eötvös Collegium szétverésében, Moszkvában lett ösztöndíjas, majd visszatért Budapestre, de a lépést elvétve Recsken kötött ki. 1956 után tudományfilozófusként nagy karriert futott be Angliában (Bandy, 2014).

A „fényes szelek” nemzedék tagjai forradalmár tudattal statisztáltak a kommunista hatalomátvételhez, elhitetvén magukkal, hogy az országot megszálló, $\mathrm{s}$ onnan nem távozó Vörös Hadsereg árnyékában lehetséges lesz egy igazságos, szocialista társadalom felépítése Magyarországon (Csepeli, 2016). A csalódás nem sokáig váratott magára. A szelek hamarosan kifakultak. A nemzedéket ott látjuk az 1956 októberében kitört szovjetellenes forradalom előkészítői és résztvevői között.

Hankiss Elemér sorspályája az 1945-ben eszmélt akadémiai nemzedék előtt álló harmadik utat követte. Nem ment külföldre, holott tehetsége, nyelvtudása, páratlan kapcsolatteremtő képessége a szabad világban sikerre predesztinálta volna. Neveltetése, polgári szabadelvű háttere azonban abban is megakadályozta, hogy belevesse magát a kommunista ideológusok által láttatni kívánt jövő projekt megvalósításába. Túl józan, túl okos, túl becsületes volt ahhoz, hogy elfogadja Lukács György kérdésbe bújtatott nyakatekert erkölcsi logikáját: „És hogyha Isten közém és a nekem rendelt tett közé a bünt helyezte volna, ki vagyok én, hogy ez alól magam kivonjam?"

\section{AZ IRODALMÁR}

A fiatal Hankiss apja nyomdokaiba lépve az irodalomtudomány müvelése iránt érzett elhivatottsághoz. 1945 után a francia és angol nyelv és irodalom tanítására jogosító oklevelet szerzett a Pázmány Péterről (majd 1950-től Eötvös Lorándról) elnevezett Budapesti Tudományegyetemen, majd ott is doktorált. Tagja volt az 
Eötvös Collegiumnak, ahol a Lakatos Imre által végrehajtott tisztogatások egyik áldozatává vált.

Az ötvenes évek szellemi-politikai környezetében Hankiss Elemér nem juthatott képzettségének megfelelő szerephez. Az egyetem elvégzését követően idegennyelv-tudását a Ferunion külkereskedelmi vállalatnál hasznosította. A vállalattól 1953-ban megvált. Az Országos Széchenyi Könyvtárban a Színháztörténeti Tár tudományos munkatársa lett. Az általa földolgozott zsebkönyvek katalógusa a magyar színháztörténeti forráskutatás és -közlés egyik alapmüve. A színháztörténet hazai és külföldi kutatói által „Hankiss-Berczeliné”-ként emlegetett kötet (és kiegészítései) a magyar színháztörténet különleges forráscsoportját tette hozzáférhetővé (Hankiss-Berczeliné, 1961).

Az 1956-os forradalom Hankisst az Országos Széchenyi Könyvtárban érte. A forradalom leverését követően hütlenség és államellenes összeesküvés vádja miatt hét hónapot töltött vizsgálati fogságban, de bizonyítékok hiányában a büntető eljárást megszüntették ellene, s folytathatta munkáját a Színháztörténeti Tárban.

Hankiss Elemér alkotó korszaka a forradalom után, a ,jól alkalmazott kegyetlenség" időszakában kezdődött. Irodalmár volt, akit az irodalmi mü maga érdekelt. A szellemi enyhülés jeleként jelent meg 1965-ben Lukács György kétkötetes nagy esztétikája, melyben az időközben kegyvesztetté vált szerző a művészet autonómiája mellett érvelt, miközben ügyesen azt a látszatot keltette, hogy hü maradt a lenini „visszatükröződés” elmélethez, amely teljes egészében tagadta a múvészet autonómiáját. Hankiss az MTA Irodalomtudományi Intézetében helyezkedett el, ahol sorra írta utóbb kötetben is megjelent irodalomesztétikai tanulmányait, melyek nem jelenhettek volna meg, ha a Szovjetunióban javában uralkodó visszatükröződés elméleten Lukács György nem üt rést.

Ez persze nem jelenti azt, hogy a marxista esztétika mégoly revizionista nézőpontjából Hankiss tanulmányai helyeselhetők lettek volna. E tanulmányokból teljes egészében hiányoztak az apriori értéktételezések. Hankiss számára nem voltak ,nagy” és „kis” müvek. Nem rágódott a frankfurti marxista iskola áldilemmáján, mely elméletileg nehezen tartható különbséget tett a „magaskultúra” és a „tömegkultúra” között. Senki nem tudott úgy behatolni a müalkotások mélyszerkezetébe, mint Hankiss Elemér. Kifogyhatatlan volt a szempontokból, melyek segítségével apróra szedte szét a müalkotást, hogy azután a tanulmány végén egyberakja, kiteljesítve a mü jelentését. Az elemzés tárgyai ugyan változtak, de a módszer, melyet kialakított ugyanaz maradt. A múvekbe hatolva hozott létre egy külön világot, melynek elemeit metszö szellemességgel katalogizálta és a hatás „gépezeteként” modellálta (Hankiss, 1969). Ebben nagy segítségére lehetett, hogy Matolcsy György, a rajzfilmek gyártására specializálódott Pannónia Filmstúdió innovatív igazgatója dramaturgiai tanácsadóként alkalmazta, így Hankiss az általa azonosított „hatásgépezeteket” a sikert sikerre halmozó rajzfilmeken tesztelhette. 
A korabeli terminológia a módszert „strukturalizmusként” azonosította, de akik nemcsak Hankiss büvészkezeire figyeltek, rájöhettek, hogy többről van szó. Hankiss ugyanis teremtette a struktúrákat, melyeket beleláttatott a müvekbe. Évtizedekkel előtte járt korának. A humor, a katarzis, a giccs struktúráit azonosítva voltaképpen szoftvereket alkotott, melyek alapján a mai informatikai lehetőségek birtokában nem lenne lehetetlen múalkotásokat létrehozni.

A Vörös Hadsereg 1968-ban leverte Prágában az „emberarcú” szocialista kísérletet. Ha nem is azonnal, a ,jól alkalmazott kegyetlenség” politikája Magyarországon megtorpant. A gazdasági reform elakadt, az ideológiai szigor újraéledt. A strukturalizmust, Hankiss Elemért név szerint is megemlítve, 1972-ben elítélte a párt Kultúrpolitikai Munkaközössége. A munkaközösség állásfoglalása szerint a strukturalisták ,a marxizmussal össze nem egyeztethető módon »világnézetként« alkalmazzák a mechanikusan átvett formalista-modernista szemléletet. Reális értékelésben el nem fogadható módon emelnek részleteket totalitássá, ezáltal elmossák vagy nihilizálják a valóságos mủvészeti értékhatárokat. (Például a Formateremtő elvek a költészetben [!] és A novellaelemzés új módszerei címü kiadványok néhány tanulmánya, egyes írásaiban Hankiss Elemér, Bojtár Endre stb.)" (Bezeczky, 2006).

Az állásfoglalás azonban nem járt a várt következményekkel. A rosszul alkalmazott kegyetlenség politikája nem tért vissza. Senkit nem bocsátottak el állásából, nem kényszerítettek emigrációba. (Az engedetlen szociológusok és a filozófusok rosszabbul jártak.) Hankiss Elemér folytathatta munkáját, melynek során az általa kifejlesztett módszer egyre távolabb sodorta tárgyától, az irodalomtól.

Rónay György és Vargha Kálmán szerkesztésében 1973-ban jelent meg egy kötet, melyben a szerkesztők a világirodalomban közmegegyezésszerủen a legszebbek között nyilvántartott verseket gyüjtöttek össze, s minden egyes vers esetében megkértek egy irodalomtudóst, hogy magyarázza el az olvasóknak, hogy az adott vers „miért szép?”. A kötetben Hankiss T. S. Eliot Marina címü versét elemzi. A bravúros elemzés azt mutatja, hogy az elemző olyan problémákat lát bele a versbe, melyek igazi helye a versen túli világ, a társadalom, ahol a költők, a versek és az olvasók vannak. A versvilágból kilépve Hankiss a költő, a vers és az olvasó közötti kapcsolatot rekonstruálja, melynek lényege, mint írja, ,a rejtélyesség, a rejtvényszerüség. Illetve az a különös lüktetés, hullámzás, ahogy valami kibontakozik a semmiből, egyre inkább megvilágosodik, de közben újra és újra visszasüllyed az ismeretlenbe, a bizonytalanba, a megfoghatatlanba. A kibontakozás és elenyészés e különös lüktetése, dinamizmusa a vers minden szintjén s jóformán minden mozzanatában megfigyelhető. Így bontakozik ki, és homályosodik el, és bontakozik ki újult erővel a költőben az újjászületés élménye, így az olvasóban a vers sokszorosan elrejtett értelme, $\mathrm{s}$ így a vers nyelvi mozzanatainak: szavainak, mondatainak jelentése." (Hankiss, 1973, 188-201.) 


\section{A SZOCIOLÓGUS}

Az irodalomtól való eltávolodást, a társadalomhoz való közelítést az 1977-ben megjelent tanulmánykötet jelezte (Hankiss, 1977). A kötetben közölt tanulmányok zöme ugyan az irodalommal foglalkozik, de az irodalmi tárgyú tanulmányok mellett egy-két tanulmányban már felbukkan az új rejtély, az érték, melynek megfejtéséhez nem az irodalom, hanem az élet adja a kulcsot.

A magyar társadalomtudomány a korban csúcson volt. Ereje abban állt, hogy a hivatalos társadalomfelfogással szemben alternatív értelmezési teret tudott adni, amelyben a hazai emberi ügyek iránt érdeklődők el tudták magukat helyezni. Hankiss érdeklődési irányának váltását jelezte, hogy 1975-ben az Irodalomtudományi Intézetből átment a Szociológiai Kutatóintézetbe, ahol Manchin Róbert és Füstös László társaságában empirikus társadalomkutatásba kezdett. A kutatás célja a magyar társadalomban elfogadott értékek vizsgálata volt. Az értékek felderítését célzó kérdőívben a Milton Rokeach által összeállított cél- és eszközértékek listáját használták fel. Mivel ugyanezt a listát használták a kutatók az USA-ban is, mód nyílott az összehasonlításra.

Hankiss szociológusként is hủ maradt önmagához (Csepeli, 2017). Látszólag elfogadta a szociológiai kutatás szabályait, nemzetközi sztenderdnek megfelelöen operacionalizált, ügyelt a reprezentatív adatfelvétel szabályaira, de valójában hagyta, hogy beinduljon a „Hankiss-gépezet”, amely a rejtvényszerüen felfogott jelenségeket kibontakoztatja a semmiből, megvilágítja azokat, majd hagyja, hogy visszasüllyedjenek az ismeretlenbe, a bizonytalanba.

Telitalálat volt az értékek választása, melyek jellegüknél fogva eleve alkalmasak voltak a Hankiss-módszer gyakorlására. Az értékek rejtőzködnek, közvetlenül nem hozzáférhetőek, létükre igazán akkor döbbenünk rá, ha eltünnek. A Semmi borzongató érzését egyedül az értékek képesek eloszlatni. Az értékek a zárt fizikai-fiziológiai létből merítik erejüket, mely az embert a számára megnyíló metafizikai világban értelmes cselekvésre hajtja. A jelentés jelentése Hankisst már strukturalista korszakában foglalkoztatta. Jól látta, hogy a jelentésképzés problémája csak akkor oldható meg, ha van fölérendelt másik struktúra, mely a jelentés jelentését szabja meg. Ennek a struktúrának a szíve lett az érték, mely az ember számára lehetővé teszi a múló fizikai létből való kilépést, beléptetve őt a kultúra által formált halhatatlan történelmi-társas létbe.

Az értékek filozófiai-antropológiai irányú kutatásának azonban még nem jött el az ideje. Az empirikus adatok megértették Hankiss-sal, hogy a kor magyar társadalma értékhiányos. Szociológusként arra vállalkozott, hogy válaszokat adjon az értékek hiánya által gyötört magyar társadalom tagjainak.

Az értékkutatás hazai mezőnye telített volt. Az értékeket a 70 -es és 80 -as években a magyar szociológia és szociálpszichológiai nem egy kiváló mủvelője kutatta. Varga Károly, Losonczy Ágnes, Váriné Szilágyi Ibolya, Vitányi Iván, Szabó 
Ildikó művei mai szemmel olvasva is hü képet adnak a magyar társadalomban kimutatható értékekről. Hankiss müveit az tünteti ki mind a mai napig, hogy ő nem abból indult ki, hogy milyen értékek vannak a magyar társadalomban, hanem abból, hogy milyen értékek hiányoznak.

Az MTA Néprajzi Kutató Csoportja és Pszichológiai Intézete, valamint a Tömegkommunikációs Kutatóközpont 1985. szeptember 2-4. között Budapesten Érték, értékkonfliktus, társadalmi változás címmel konferenciát rendezett, melyen a magyar értékkutatatás színe-virága részt vett. A kötet egyik szerkesztője, Hoppál Mihály szerint Hankiss dolgozata ,abból indul ki, hogy a kultúra és a társadalmi lét legkülönbözőbb szférái egyetlen összefüggő egész részei, amelyek összefüggnek egymással. Vagyis a rosszul múködő gyárak, illetve a gazdaság és a rosszul működő társadalom, illetve emberi kapcsolatok mind ugyannak a jelenségnek a más-más oldalai. A rendszer egyik részének »rendetlensége « - vagy ahogy ő mondja - »pongyolasága«, kihat más területekre is. Sorra veszi az okokat, a történelmi mentségeket, amelyeket a köztudat általában fel szokott sorakoztatni (történelmi tragédiák sora, a függetlenség és az autonómia hiánya, a paradigmák torlódása többek között. Hankiss már évek óta a rejtett mechanizmusok (lásd »második gazdaság«) müködését vizsgálja a mai magyar társadalomban. Nem áll meg a tények megállapításánál, az okokat is felkutatja (például az oktalan pusztítás a régi rend eltörlése nevében, a régi közösségek szétrombolása, a jól müködő értékrendek denunciálása és a hiánygazdaság értékromboló hatása).” (Hoppál, 1987, 9.)

Az 1986-ban tartott elöadás a „Hankiss-gépezetet” teljes fegyverzetében mutatja meg. Az előadó a magyar társadalom értékhiányait tűzijátékszerű felsorolásban tizennyolc dimenzió mentén adja meg, mindegyik esetben nem egyszerüen reagálva, hanem teremtve az adott dimenziót (Hankiss, 1987). Ezáltal jön létre a különös lüktetés a kibontakozás és elenyészés között, melyre T. S Elliot Marina címủ versének elemzése kapcsán láttuk a példát.

Az egyes dimenziók címei felrúgták a kor szociológiájában megszokott szcientista, köznapi ésszel felfoghatatlan, csak a beavatottak számára érthető szakkifejezések alkalmazásának kötelmét. A címek párbeszédre szólították fel az olvasót, azt éreztetve vele, hogy egyenrangú társa a kutatónak, aki vezet, megmutat, kérdez, de semmiképpen sem oktat, nem tudja a „tutit”. A tizennyolc dimenzió címe mindössze három esetben állítás.

Kiindulásként a történelem jelenik meg, melynek címe: „A török áfium, avagy: mindennek a történelem az oka". Az egyes dimenziók címében csak néhány esetben jelenik meg puszta állítás. „Átmeneti ország”, „Paradigmák torlódása, avagy: azt sem tudjuk már, hol áll a fejünk”, „Add tovább, szamár..., avagy: az egyetemes felelőtlenség paradicsoma".

A címadó állításokat a legtöbb esetben kérdések követik, melyek megválaszolására a szerző mintegy felszólítja az olvasót, a hallgatót. „Autonómia hiánya, avagy: valóban összefügg-e a Szabadság és a Rend?”, „A késlekedő polgárság, 
avagy: nem polgári huncutság az egész?”, „Félbemaradt társadalom: avagy: meddig kell még loholnunk a szekér után?”, „Kudarcra ítélt ország, avagy mit (sem) ér az ember, ha magyar?”, „Új rend és új rendetlenség, avagy: robbantsuk fel a Nemzeti Színházat?”, „Életformák pusztulása, avagy: hogyan kerül fel a disznó a loggiára?”, „A szegénység, avagy: még az ág is minket húz?”, „A hiány patologizáló hatása, avagy mindegy, hogy milyen, csak legyen?”, „A rajtunk kívül álló okok országa, avagy Miért nekem mondja? Tehetek én róla?”, „Az elvárások hiánya, avagy: jó ezeknek így is?”, „Négy-ötfös országok, avagy, hol szemetel a takaros háziasszony?”, „Senkiföldje, avagy: mit nekem ti zordon Kárpátok?”, „Egy mindenkiért? Mindenki egyért? Avagy: Miért szőjem a selymet elvtárs?”, „Fiat ordo et pereat mundus? Avagy: csináljunk tüzzel-vassal rendet?”.

Az előadás szövege megjelent a Valóság címü folyóiratban, mely a kor értelmiségi közönsége számára kötelező olvasmányokat rendre megjelentette. Az előadás összefoglalta a szerző 70 -es évek végén, 80-as évek elején született müvekben kifejtett gondolatait, folytatva a Hankiss nagy korszakában született müvek sorát, melyek a kor magyar társadalmának cselekvői számára elrejtett jelenségeket az el nem rejtettségbe emelték (Hankiss, 1983). Ebben az időszakban kezdődött Hankiss páratlan médiakarrierje. Müsorainak nézői, hallgatói, interjúinak olvasói az igazság megtörténését tapasztalhatták meg.

\section{A POLITOLÓGUS-POLITIKUS}

A rendszerváltozást Hankiss politológusként érte meg. Az államszocialista rendszer szorításából való kilábalás lehetőségeit tárgyaló könyve 1989-ben került a boltokba. A megjelenés pillanatában még „nagyfeszültségü” könyvet Pozsgay Imre és Ágh Attila lektorálása tette a halódó rendszer számára elfogadhatóvá. A szerző a tőle megszokott invenciózussággal a könyvben valósággal ontja a küszöbönálló változás lehetséges forgatókönyveit, melyek alapján inkább Magyarország, mintsem a Szűcs Jenő által közép-kelet-európainak nevezett európai fejlődési régió jövőjét próbálja elképzelhetővé tenni.

A könyvet megjelenése pillanatában heves támadás érte az akkor éppen induló baloldali-liberális szemléletű Budapesti Könyvszemlében (Vági, 1989). A bíráló nemcsak a szakmai kompetenciát, hanem a politikai tisztességet is elvitatta Hankisstól. A velejéig politikai indíttatású bírálat mutatta, hogy a rendszerváltozás révén újraszerveződött politikai térben Hankiss Elemérnek nem lesz helye.

A demokratikus, független, konzervatív-liberális magyar politikai elitet az 1944-es és az 1948-as két totalitárius fordulat megsemmisítette. A német megszállással és a németek által támogatott szélsőséges jobboldali politikával szembeforduló értelmiségiek és politikusok sorsa az üldözés, a letartóztatás és a deportálás volt. Az 1948-ban berendezkedett államszocialista rendszer nem türte a 
szellemi függetlenséget, demokratikus politikai elkötelezettséget, a Nyugat értékeihez való ragaszkodást. A totalitarianizmus 1944-ben elhintett magvai 1948 után kikeltek, és szárba szöktek. A 80-as években, értékszociológiai müveiben éppen Hankiss Elemér mutatott rá, hogy a totalitarianizmus iránti hajlandóság nem a semmiből jött. A magyar társadalom az 1944-es fordulat előtt nem volt makulátlan demokrácia. A tekintélyelvüség, az infantilizmus, a paternalizmus széles tömegeket tett süketté és vakká az egymástól elválaszthatatlan demokrácia és kapitalizmus értékeivel szemben.

Az 1989-ben mindenki meglepetésére villámcsapásszerüen bekövetkezett rendszerváltozás tragédiája az volt, hogy nem volt független elit, mely képes lett volna a rendszerváltozás ígéretét valóra váltani. 1948 és 1989 között nem voltak meg a feltételek ahhoz, hogy az 1944-48 között megsemmisített demokratikus elit újraszervezze magát. Voltak persze, akik függetlenek maradtak, de hálózatosodás, szellemi infrastruktúra hiányában szavaik nem értek el a néphez.

A rendszerváltozás által teremtett politikai ürben egy pillanat alatt megszerveződtek a szekértáborok, melyek identitását nem saját értékeik, hanem a múltban egymásnak okozott sérelmeik adták. Sérelmek, mint arról éppen Hankiss beszélt korábban, bőven voltak mindkét oldalon. A jobboldal felhánytorgatta az 1948 után létrejött szocialista rendszerben elszenvedett megpróbáltatásokat, melyek tényleges szenvedéseket és igazságtalanságokat jelentettek. A baloldal felhánytorgatta az 1944-ben és azelött történteket, melyek százezreket vittek az értelmetlen halálba. A megosztottság lehetetlenné tette az egymásnak okozott traumák kibeszélését, megvitatását.

Az 1945 óta megtartott első szabad választás 1990-ben a jobboldal győzelmét hozta. Az első szabadon választott magyar kormány miniszterelnöke Antall József lett, akinek apja, id. Antall József a Kállay-kormány időszakában éppúgy magas beosztást töltött be, mint Hankiss János. Talán ez is közrejátszott, hogy Antall József 1990-ben Hankiss Elemért kérte föl a Magyar Televízió elnöki posztjának betöltésére, aki ezt a felkérést el is fogadta.

A politológus belépett a politikába. Ezt a forgatókönyvet a kelet-európai alternatívákat tárgyaló mü szerzője sem látta előre. Hankiss a támadások pergőtüzébe került, mind jobbról, mind balról. Már 1990 őszére kiderült, hogy a szélsőségesen polarizált politikai térben lehetetlen a független, demokratikus, egyedül a közjóra figyelő magatartás, melynek hagyományát a családi otthonból hozta magával. Az 1990 őszén kirobbant taxisblokád zürzavarában a tévéelnök gyanútlanul besétált a csapdába, s elveszítette mindkét oldal bizalmát. 1993. január 6-án benyújtotta lemondását. A lemondást megelőzően azonban máig feledhetetlen leckét adott a magyar társadalomnak a demokráciáról. A Parlament Kulturális Bizottsága 1992 nyarán hat és fél órán át hallgatta meg Hankiss Elemért, aki a legkülönbözőbb rosszindulatú vádak pergőtüzét állva válaszolt. A meghallgatás alapján televízióműsor készült, melynek főhőse az igazságtalanul megvádolt, igazát védő elnök. 


\section{A REFORMER}

A tévéelnökség meghiúsulása nem vette el Hankiss Elemér kedvét a társadalmi ügyekkel való foglalkozástól. Új reformkort hirdetett, melynek központi témái sorába a politikai hovatartozástól függetlenül a helyi gazdasági és közösségi fejlődés, az innováció, a kutatás, az oktatás, a konfliktusmegoldás ügyeit állította. Hankiss Elemér helyesen ismerte föl, hogy a 21. században Magyarország elött álló politikai gazdasági és társadalmi kihívásokra nem lehet a 20 . században bevált módon reagálni.

E felismerés jegyében a 90-es évek kezdetétől fogva Miszlivetz Ferenccel együttmüködve tevékeny részt vállalt a Köszegen létrejött oktatási és kutatási mühely létrehozásában és továbbfejlesztésében, amely a magyar akadémiai életben teljesen újszerủ intézményi kereteket biztosít a természet- és társadalomtudományok kutatóinak együttműködése, az alap- és alkalmazott kutatások integrálása, a legjobb helyi és közép-európai város- és közösségfejlesztő gyakorlatok kibontakoztatása számára.

A kormány rendeletével 2015-ben Köszegen létrejött Felsőbbfokú Tanulmányok Intézete alapgondolata már megjelent az 1990-ben létrehozott Európa Kutató Alapítványban, mely a szombathelyi Berzsenyi Dániel Főiskola Szociológia és Politikatudomány Tanszéke, valamint az MTA Szociológiai Kutatóintézete közös kezdeményezése volt. Köszegen 1994-ben megnyílt az Európa Ház, 2005-től ebben a városban kerül megrendezésre a Nyári Egyetem, melynek előadói között rendszeresen ott szerepelt Hankiss Elemér is.

Az 1989/90-es rendszerváltó évtől távolodva egyre inkább nyilvánvalóvá vált, hogy a magyar társadalom nem képes megszabadulni a múlt társadalomlélektani örökségétől, melynek egyik legnagyobb hatású leírója és éles szemü elemzője éppen Hankiss Elemér volt. Ha valaki, akkor ő tudta, hogy a negativizmus, a bizalomhiány, a nemzeti öncélúság, az üres individualizmus hagyománya lidércnyomásként nehezedik a jelenben élők érzéseire és gondolataira. Az információs társadalom adta kommunikációs lehetőségekre alapozva társadalmi mozgalmakat hirdetett, melyektől azt remélte, hogy új horizontokat nyitva alulról felfelé elindítják a társadalmi látásviszonyok tisztulását. Meghirdette az interneten a „Találjuk ki Magyarországot!”, majd a „Találjuk ki Közép-Európát!” és az „Új Reformkor” mozgalmakat. Meggyőződése volt, s ki is mondta, hogy csak úgy történhet változás, ha közösen gondolkodunk. Az internet természetes fóruma lehet a közös gondolkodásnak, a közös cselekvés előkészítésének. Ha mindenki tesz egy lépést önmaga, családja, települése érdekében, azzal az ország, a vidék felemelkedését is szolgálja. Sok-sok egy lépésből végül tízmillió lépés lehet.

Az ezredfordulón a következő, rá igen jellemző kérdéseket tette föl, melyek megválaszolása ma éppúgy aktuális, mint volt megfogalmazásuk idején: 
„Van-e lehetőség »Új Kiegyezésre« Közép-Európa kettéhasadt társadalmaiban?” „Hogyan lehetne egy igazságosabb társadalmi rendet felépíteni?”

„Magyarország arculata: mi lehetne az ország emblémája, »védjegye«, »brand«je, mik azok az adottságok, kezdeményezések, teljesítmények, amelyek értékessé és versenyképessé tehetnék az országot a világban?" „Hogyan viselkedik, él, gondolkodik egy ideális »európai polgár«?” „Miért rosszkedvűek a közép-európai társadalmak?”

„Könnyebb vagy nehezebb ma tisztességes emberként élni, mint volt ez mondjuk 25, 50 vagy 100 évvel ezelött? Miért igen, miért nem?"

„Ha élne, mit tenne ma Széchenyi István, Kossuth Lajos vagy Deák Ferenc? (Illetve mit tennének a többi országok hajdani nagy államférfijai, ha ma élnének?)"

A weboldalak folyamatosan tájékoztatták a résztvevőket az új gondolatokról, figyelemre méltó kezdeményezésekről és megoldásokról, amelyek segíthették a felhasználókat abban, hogy „kitalálják” önmagukat, magatartásnormáikat, életstratégiájukat, emberi kapcsolataikat, közösségeiket, falvaikat, városaikat, országukat. Állandó eszmecserét, információáramlást tettek lehetővé a közösség tagjai között, vitákat kezdeményeztek olyan témákról, amelyek elősegíthették az egyének, a családok, a helyi közösségek előbbre jutását.

Az Országstratégiák rovat írásai azt kutatták, hogy miként válhatna minden közép-európai nemzet a maga módján, a „kiválóság szigetévé”. Számos írás tárgyalta a fenntartható fejlődést szolgáló siker feltételeit.

A közép-európai régió sok országára, köztük Magyarország társadalmára jellemző, hogy két vagy három részre szakadt, éles ellentétek állítják szembe az embereket egymással, és a táborok szinte beszélni sem hajlandóak egymással. Ez az áldatlan helyzet lehetetlenné teszi az együttmüködést, rontja az adott országok lehetőségeit, gátolja fejlődésüket. Az Új kiegyezés rovat írásai arra a kérdésre keresték a választ, hogy miként lehetne megteremteni a társadalmi békét.

Tervezték, hogy elkészítik Magyarország tehetségtérképét. Ezen a térképen azok a tehetséges és elkötelezett emberek lennének megtalálhatóak, akik valami fontosat tettek, alkottak a saját körükben. Polgármesterek, társadalmi menedzserek, kreatív elmék, feltalálók, kiváló tanárok, közösségszervezők, moderátorok, vállalkozók, iparosok, akik valamennyien motorjai lehetnek a változásoknak. Így láthatóvá vált volna a tehetségek hálózata, akik egymásról tudva, egymást segítve egy országos crowdsourcing problémamegoldás részeseivé válhattak volna.

Az interneten elérhető „Találjuk ki Magyarországot”, „Találjuk ki Közép-Európát”, „Az Új Reformkor” kezdeményezések ereje azonban megtört, mivel az ezredfordulón az internetelérés Magyarországon még messze nem volt elegendő ahhoz, hogy a weblapok mozgósító erejében bízva mozgalmat lehessen fenntartani.

Hankiss diagnózisainak ereje mindmáig nem szünt meg, mivel nem szüntek meg a hiányok, melyekre Hankiss reflektált. A párbeszéd Hankiss és a magyar 
társadalom között a múlt század 70-es éveinek végén, Hankiss szociológusi fordulatát követően kezdődött, a rendszerváltást követő évtizedekben folytatódott. A párbeszéd fenntartása a kőszegi Felsőfokú Tanulmányok Intézete keretében létrehozott Hankiss Központ feladata lesz.

\section{PUBLIC INTELLECTUAL}

A televízióelnökséggel lezárult Hankiss rövidre szabott politikai karrierje. Viszszatért az írás, az oktatás világába, melyet kiegészített a népművelés. Egyre számosabbak lettek szereplései, melyekben állást foglalt a nyugati civilizáció sorskérdéseiben, kinyitotta a teret a végtelenbe Istent keresve és kérdezve. Könyvei egyre átfogóbb témákat tárgyaltak. A szüken vett filozófusi céh ezeket a könyveket nem fogadta el (Sümegi, 2015), de a könyveket olvasó, az interjúkat néző és hallgató közönség szemében Hankiss Elemér gondolatai egyre inkább mércévé, vonatkoztatási keretté lettek. A szakkritika nem vette vagy nem akarta észrevenni, hogy Hankiss az ezredforduló táján annak a szellemi köztársaságnak lett polgára, ahova elötte Szalay László, Eötvös József, Bibó István, Karácsony Sándor nyertek bebocsáttatást.

Hankiss irodalomtudósként lépett be a magyar szellemi életbe, s pályáját public intellectualként fejezte be. Sok életet élt. Az életmű vége felől visszanézve látható, hogy a sok élet végső soron egyetlen irányba tartott. Utolsó, korábbi müveinek lényegi megállapításait megismétlő, summázó mủve jellegzetesen $A$ befejezetlen ember címet kapta. A cím látszólag kijelentés, de valójában felszólítás.

\section{IRODALOM}

Bandy, A. (2014): A Csokoládé-gyilkosság. Egy filozófus másik élete. Budapest: Akadémiai Kiadó

Bezeczky G. (2006): A strukturalizmus Magyarországon. 2000. 4, 64-76. http://ketezer. $\mathrm{hu} / 2006 / 04 / \mathrm{a}-$ strukturalizmus-magyarorszagon/

Csepeli Gy. (2016): Az identitáskereső identitása. socio.hu/uploads/files/2016_1/csepeli_pataki. pdf

Csepeli Gy. (2017): Hankiss Elemér és a magyar szociológia. In: Takács M. J. (szerk.): Hankiss-emlékkönyv. Budapest: Helikon Kiadó

Csepeli Gy. - Méhes G. - Fournier, M. (2015): Egy élet pályája: Életútinterjú Szabó Dénes kriminológussal. Budapest: NKE Szolgáltató Nonprofit Kft.

Hankiss E. (1969): A népdaltól az abszurd drámáig: Tanulmányok. Budapest: Magvető Kiadó

Hankiss E. (1973): T. S. Eliot: Marina. In: Rónay Gy. - Vargha K. (szerk.): „, Miért szép?” A világirodalom modern verseiböl. Budapest: Gondolat Kiadó

Hankiss E. (1977): Érték és társadalom: Tanulmányok az értékszociológia köréből. Budapest: Magvető Kiadó

Hankiss E. (1983): Társadalmi csapdák. Diagnózisok. Budapest: Magvető Kiadó 
Hankiss E. (1987): A társadalmi értékek válságáról. In: Hoppál M. - Szecskő T. (szerk.): Értékek és változások. Budapest: Tömegkommunikációs Kutatóközpont

Hankiss E. (1989): Kelet-európai alternativák. Budapest: KJK

Hankiss E. (2014): A befejezetlen ember. Budapest: Helikon Kiadó

Hankiss E. - Berczeli A. K. (1961): A Magyarországon megjelent színházi zsebkönyvek bibliográfiája: XVIII-XIX. század. Budapest: OSZK

Hoppál M. (1987): Előszó. In: Hoppál M. - Szecskő T. (szerk.): Értékek és változások. Budapest: Tömegkommunikációs Kutatóközpont

Hoppál M. - Szecskő T. (1987): Értékek és változások. Budapest: Tömegkommunikációs Kutatóközpont

Kornai J. (1980): A hiány. Budapest: KJK

Losonczy Á. (1977): Az életmód az időben, a tárgyakban és az értékekben. Budapest: Gondolat Kiadó

Machiavelli, N. (1978): A fejdelem. (ford. Lutter É.) In: Machiavelli, N.: Niccolò Machiavelli müvei I. köt. Budapest: Európa Kiadó

Mannheim K. (2000): A nemzedékek problémája. In: Mannheim Károly: Tudásszocológiai tanulmányok. Budapest: Osiris Kiadó

MSZMP KB Kultúrpolitikai Munkaközösség (1972): Irodalom- és művészetkritikánk néhány kérdése. Az MSZMP KB mellett működő Kultúrpolitikai Munkaközösség állásfoglalása. Társadalmi Szemle, 27, 10, 26-39.

Pataki F. (2005): A Nékosz legenda. Osiris Kiadó

Sümegi I. (2015): „Saját kényemre, szabadon”. Hankiss Elemér filozófiai munkáiról. BUKSZ, $3-4 ., 131-140$.

Szabó I. (1992): Az ember államositása: Politikai szocializáció Magyarországon. Budapest: Tekintet Kiadó

Szűcs J. (1983): Vázlat Európa három történeti régiójáról. Budapest: Magvető Kiadó

Vági G. (1989): Híres mesterségem címere P. Hankiss Elemér: Kelet-európai alternatívák. BUKSZ, $1,1,63-66$.

Varga K. (1968): Magyar egyetemisták életfelfogása. Budapest: Akadémiai Kiadó

Váriné Szilágyi I. (1987): Az ember, a világ és az értékek világa. Budapest: Gondolat Kiadó

Vitányi I. (1986): Az „Európa-paradigma”. Európai kultúra, világkultúra. Budapest: Magvető Kiadó 